
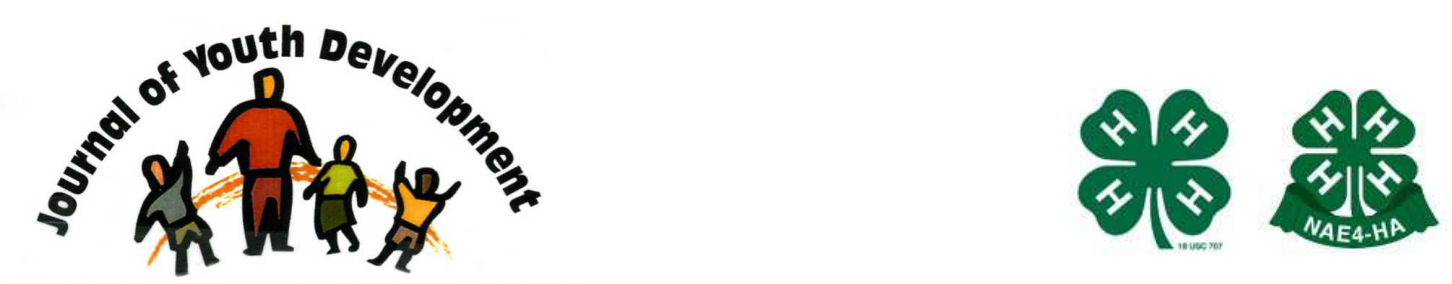

Bridging Research \& Practice

\title{
Ladders to Leadership: What Camp Counselor Positions Do for Youth
}

\author{
Darcy Tessman \\ 4-H Youth Development \\ University of Arizona, Cochise County \\ Sierra Vista, AZ \\ dtessman@cals.arizona.edu \\ Stefanie L. Duda \\ 4-H Youth Development \\ University of Florida, IFAS Extension, Leon County \\ Tallahassee, FL \\ sduda1@ufl.edu
}

Dale Pracht

Family, Youth and Community Sciences

University of Florida, IFAS Extension

Gainesville, FL

dpracht@ufl.edu 


\title{
JOURNAL OF YOUTH DEVELOPMENT \\ bridging research and practice

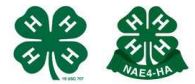

\section{Ladders to Leadership: What Camp Counselor Positions Do for Youth}

\author{
Darcy Tessman \\ University of Arizona \\ Stefanie L. Duda and Dale Pracht \\ University of Florida
}

\begin{abstract}
The 4-H youth development organization understands and has recognized residential camping as one of the major modes of program delivery. Primary benefactors of the residential camping program are those youth who serve as camp counselors. Not only are they recipients of the educational program, but also supervise and teach younger campers (Garst, \& Johnson, 2005; McNeely, 2004). As a result of their experience, camp counselors learn about and develop leadership and life skills (Thomas, 1996; Purcell, 1996).

The residential camping experience allows youth to serve as volunteers through their role as camp counselors. In addition to the benefits earned from their volunteer role, residential camping provides youth camp counselors the opportunity to gain leadership skills (Arnold, 2003) as well as add to the camp structure, planning, and implementation (Hines, \& Riley, 2005).
\end{abstract}

\section{Introduction}

The 4-H youth development organization understands and has recognized residential camping as one of the major modes of program delivery. Primary benefactors of residential camping programs are those youth who serve as camp counselors. Not only are they recipients of the educational program, but also supervise and teach younger campers (Garst, \& Johnson, 2005; McNeely, 2004). As a result of their experience, camp counselors learn about and develop leadership and life skills (Thomas, 1996; Purcell, 1996).

\section{4-H Residential Camping}

Across the United States, residential camping programs differ. However, outcomes of these programs show life skill development in areas such as: (1) making new friends, (2) cooperation, 
(3) accepting differences, (4) responsibility, and (5) teamwork (Arnold, Bourdeau, \& Nagele, 2005; Garst, \& Bruce, 2003; Garton, Miltenberger, \& Pruett, 2007; Thurber, et al., 2007). Specifically, research has shown that youth who serve as camp counselors gain skills such as leadership, responsibility, teamwork, decision making, social and group facilitation skills (Brandt ,\& Arnold, 2006; Duda, 2009; Duncan, 2000; Garton, Miltenberger, \& Pruett, 2007; Forsythe, Matysik, \& Nelson, 2004; Garst, \& Johnson, 2005; McNeely, 2004).

\section{Volunteerism and 4-H Residential Camping}

According to the Corporation for National and Community Service, (2005) an estimated 15.5 million U.S. adolescents age 12-18 are volunteers. There are many reasons to encourage youth to serve in such a capacity. Studies have found that youth volunteerism is helpful in developing social skills and a sense of belonging (Sundeen, \& Raskoff, 1994). Hart, et al. (2007) found that the frequency in which high school seniors volunteer was a predictor of their volunteering habits nearly a decade later. Adults who volunteered as youth are twice as likely to volunteer as their counterparts who did not (Toppe, et al., 2002). Volunteerism has been linked to an increase in self-esteem, self-acceptance, and self-efficacy (Marta, \& Pozzi, 2008) and allows youth to evaluate themselves as "producers rather than consumers" (Logan, 1985).

The residential camping experience allows youth to serve as volunteers through their role as camp counselors. In addition to the benefits earned from their volunteer role, residential camping provides youth camp counselors the opportunity to gain leadership skills (Arnold, 2003) as well as add to the camp structure, planning, and implementation (Hines, \& Riley, 2005).

\section{Leadership, Education, and Adventure for Pre-Teens (LEAP) Camp}

In southeastern Arizona, LEAP Camp provides an overnight camping opportunity for 11-13 year old youth. LEAP is unique in that the camping experience is conducted mainly by youth camp counselors 14-18 years of age - under the supervision of an Extension Agent. There are two basic levels of camp counselors. Junior counselors are ages 14-15. Senior counselors are ages $16+$. Junior and senior counselors work together with up to six campers in a cabin. They are constant companions to the campers. They share the same bathroom, eat at the same table, and attend all of the daily workshops together. Junior counselors never leave their campers. They accompany a camper to the infirmary, are their buddy for bathroom or water breaks, and are constantly taking a head-count of the campers to make sure everyone is together. Senior counselors have the same duties except they are responsible for teaching the workshops that campers and junior counselors attend.

\section{Camp Counselor Preparation}

Two pre-camp counselor events are held. The first is to plan the theme, schedule, and workshops for camp. The second event is the camp counselor training. At each of these events, expanded leadership roles are available for senior counselors and for chaperones-in-training (CITs). A chaperone-in-training is a young person, typically a former senior counselor, who is still interested in working on LEAP Camp activities, but is not yet 25 years of age so they can be a certified camp chaperone - many are college students.

\section{The Planning Session}


At the planning event, CITs and senior counselors are paired to lead brainstorming groups for the types of workshops that will be held at camp, educational opportunities, adventure, community service, logo/publicity/marketing, group building/games. The agent provides internet access, books, curriculum, and other resources to allow for research and idea gathering. Teams report their decisions to the greater group to refine plans and gather feedback. A master schedule is filled in by the counselors as plans are agreed upon. At the close of the planning event, lists of needed supplies are given to the agent and each group has divided tasks to be completed prior to the next camp counselor event. Schedules are made for counselors to visit 4-H clubs to promote camp.

\section{The Training Session}

A small group of senior counselors work with the Extension agent to plan, organize, and implement the camp counselor training session. These counselors (Senior + ) are the most seasoned and serve as peer trainers to younger counselors. At the training event, senior counselors teach the arts and crafts and community service projects so the counselor team will have experience making all of the items prior to camp. Through a youth/adult partnership or as a peer trainer, senior + counselors teach younger counselors about risk management, roles and responsibilities, common happenings, and camp discipline and rules.

\section{Where Research Meets Practice, Climbing the Ladder}

As youth enter the camp counselor process, they start at the junior counselor level. At this point, the Conscious Competence Ladder (Fig. 1, Morell, Sharp, \& Crandall, 2002) expects these new counselors to exercise "unconscious incompetence." They do not know what they do not know. Many of these counselors have attended LEAP Camp as campers, but have not processed the role or responsibility required to be a counselor.

Figure 1

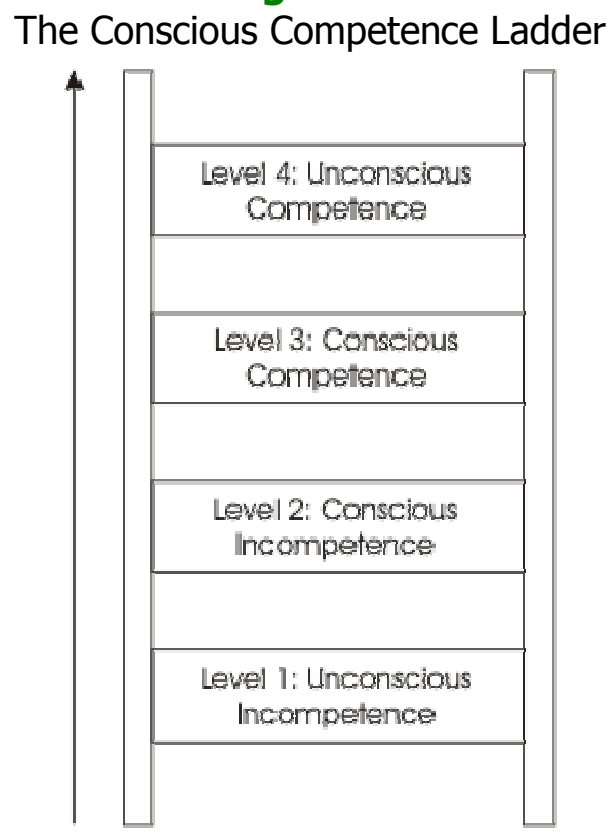

As youth move from junior to senior counselors they progress from "unconscious incompetence" to "conscious incompetence." They realize what they do not know and progress to "conscious 
competence" as they work to obtain the skills taught and practiced in camp counselor training and during camp. While each young person progresses at their own pace, many will evolve to "unconscious competence" when they are at the senior and/or senior + counselor roles as they teach youth at camp or other counselors at camp counselor training.

The multiple levels of leadership in the camp counselor program are designed around Vzgotsky's Zone of Proximal Development (Fig. 2) which believes that young people develop from interactions with more knowledgeable others.

Figure 2

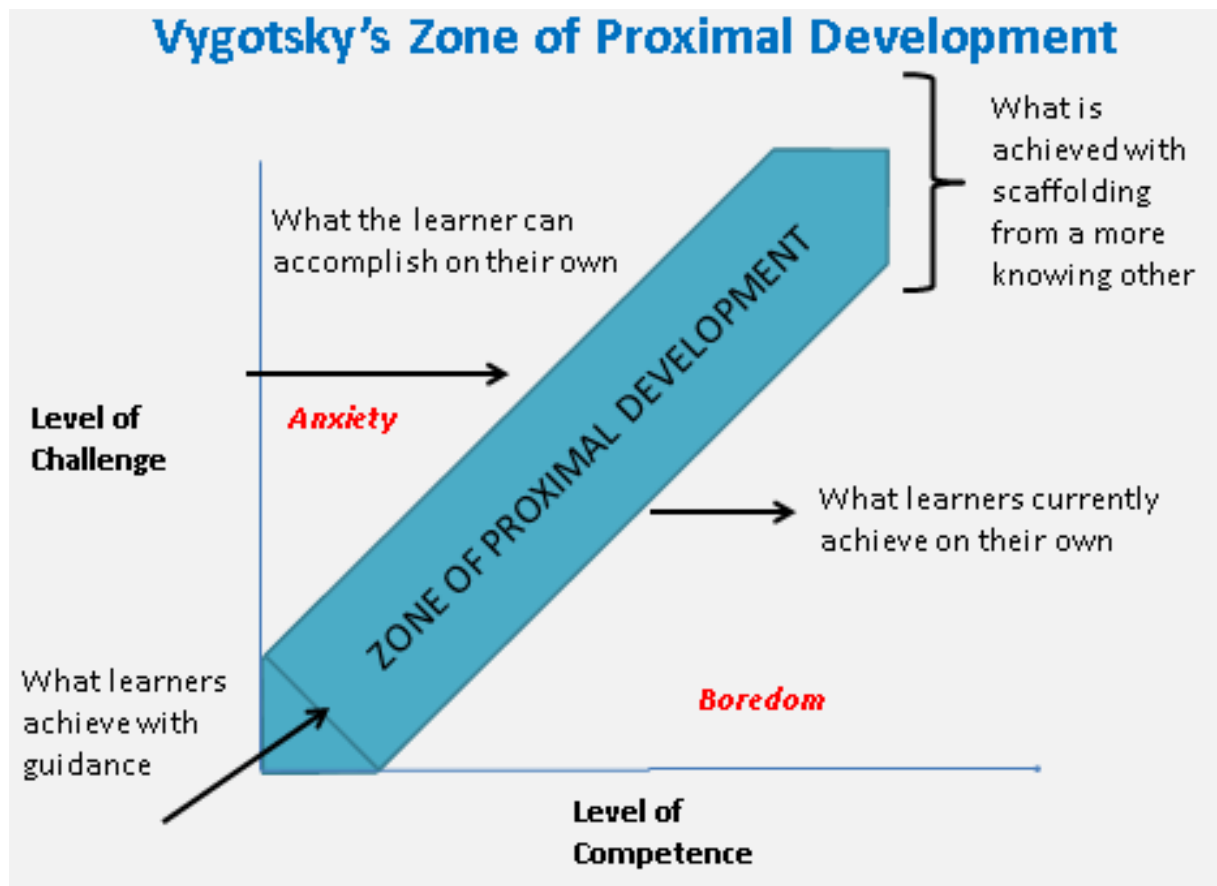

These "knowledgeable others" provide guidance for youth at a point just beyond their current level of understanding (Schaeffer, 2006). This is combined with van Linden and Fertman's (1998) stages of adolescent leadership development: awareness, interaction, and mastery. They contend that youth leadership progresses not sequentially, but fluidly. Adolescents may progress through a stage, only to return to it and pass through it again at a later date. In awareness, youth notice leadership potential in themselves and others. The interaction stage occurs when youth start to explore leadership, while mastery involves the actual practice of leadership concepts.

\section{Method}

The Arizona Life Skills Assessment Tool was administered at LEAP Camp Counselor training as well as at LEAP Camp. Life skill outcomes were chosen as measurements of quality because Family Living and 4-H Youth Development programs work to teach youth and adults the life skills necessary to become capable, competent and caring citizens. The life skills model "Targeting Life Skills" from Iowa State University was used as a model to create this system. Specific life skills have been selected at Washington State University Extension (from where the Arizona tool was purchased) to measure on a statewide basis. They were chosen through a 
consensus process with input from over 70 Family Living and 4-H Youth Development educators.

There are eight Life Skills Indicators in the Likert Scale post/pre, retrospective survey: Decision Making, Leadership, Wise Use of Resources, Useful / Marketable Skills, Communication, Healthy Lifestyle Choices, Accepting Differences, and Self-Responsibility.

Validity of the system was tested at several levels:

- $\quad$ First, the life skills indicators were created by a team of Extension Specialists and county educators.

- Next, the indicators were assessed by the team for face validity.

- Then the indicators were piloted on program participants.

- Finally, a statistical analysis, called a factor analysis, was run to determine validity.

Reliability of the system was tested through a statistical analysis called a Cronbach's Alpha. Camp Counselor results represent surveys from 2005-2007, 2009-2011. For each indicator the pre and post mean score is given. $1=$ no, $2=$ sometimes, $3=$ usually, $4=y e s$

\section{Chart 1}

Life Skill of Accepting Differences $\mathrm{N}=15$

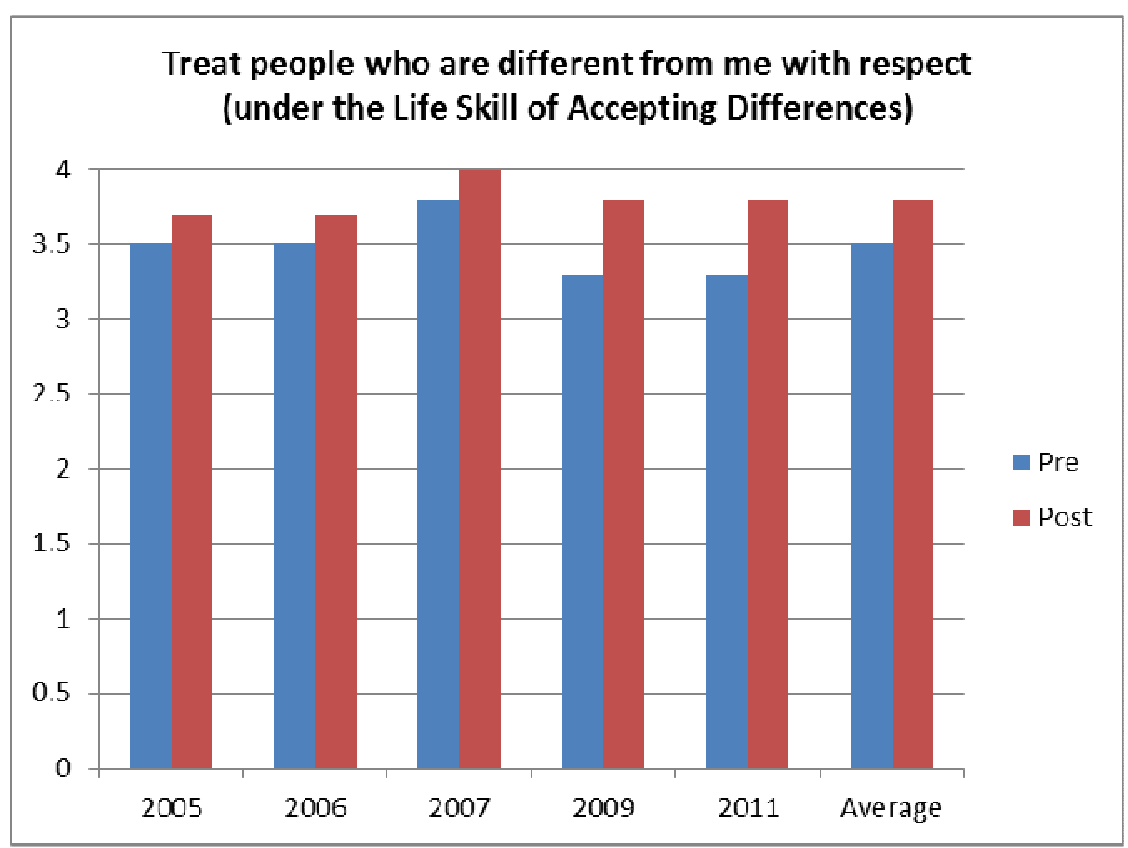


Chart 2

Life Skill of Leadership $\mathrm{N}=15$

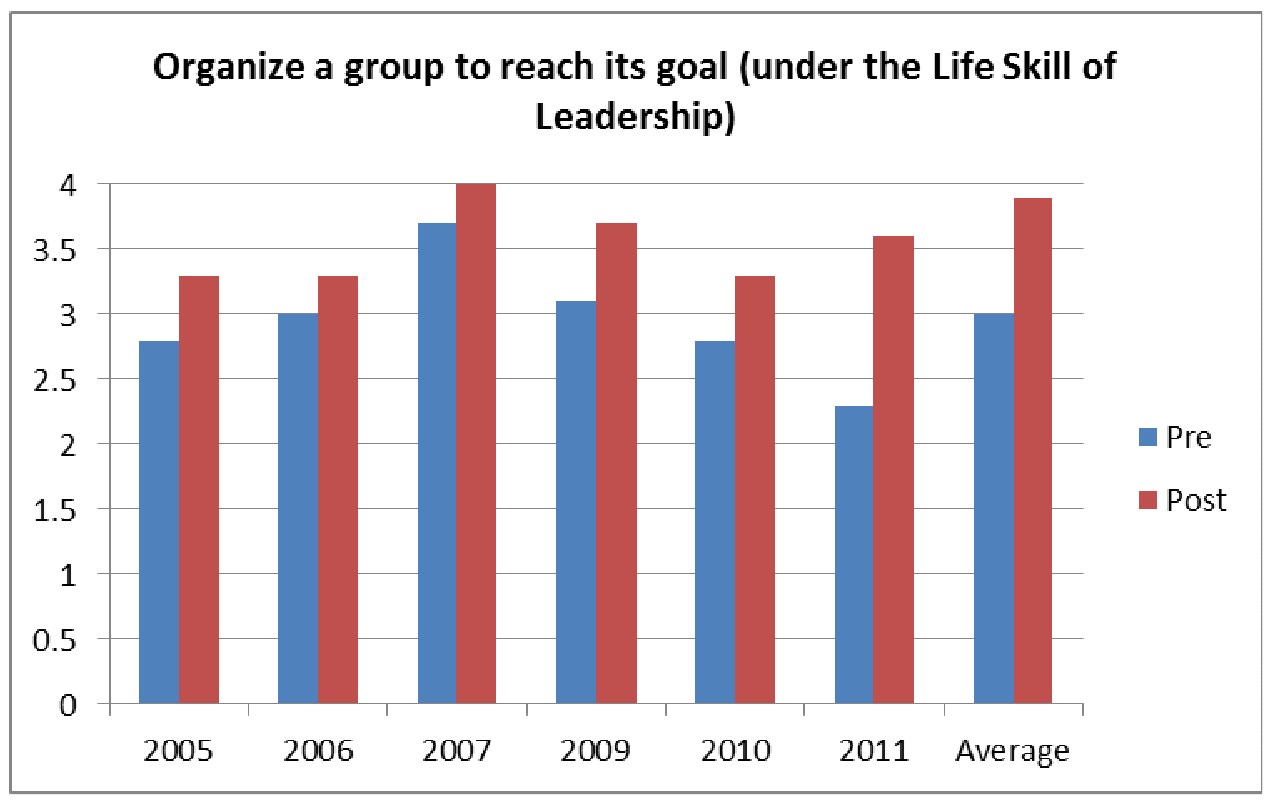

Chart 3

Life Skill - Useful/Marketable Skills $\mathrm{N}=15$

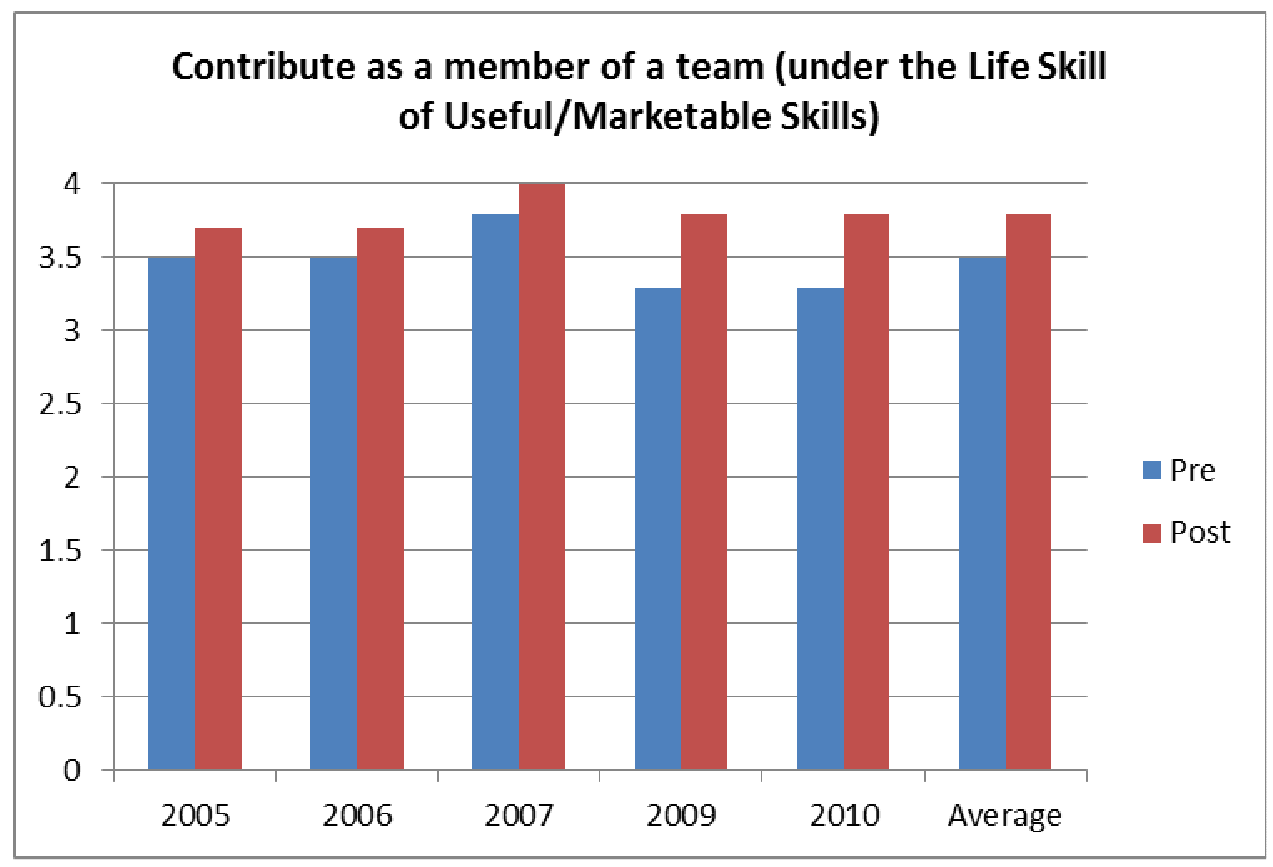




\section{Chart 4}

Life Skill of Communication $\mathrm{N}=15$

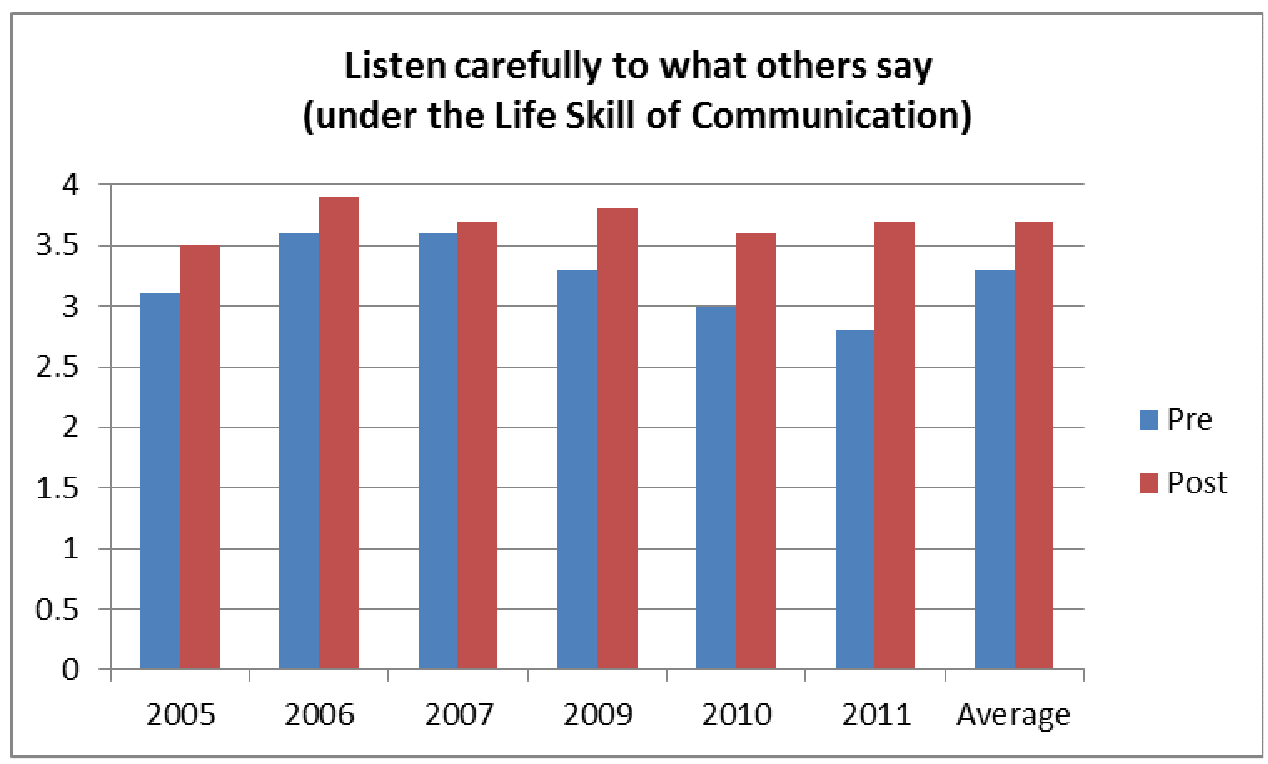

Chart 5

Life Skill of Self Responsibility $\mathrm{N}=15$

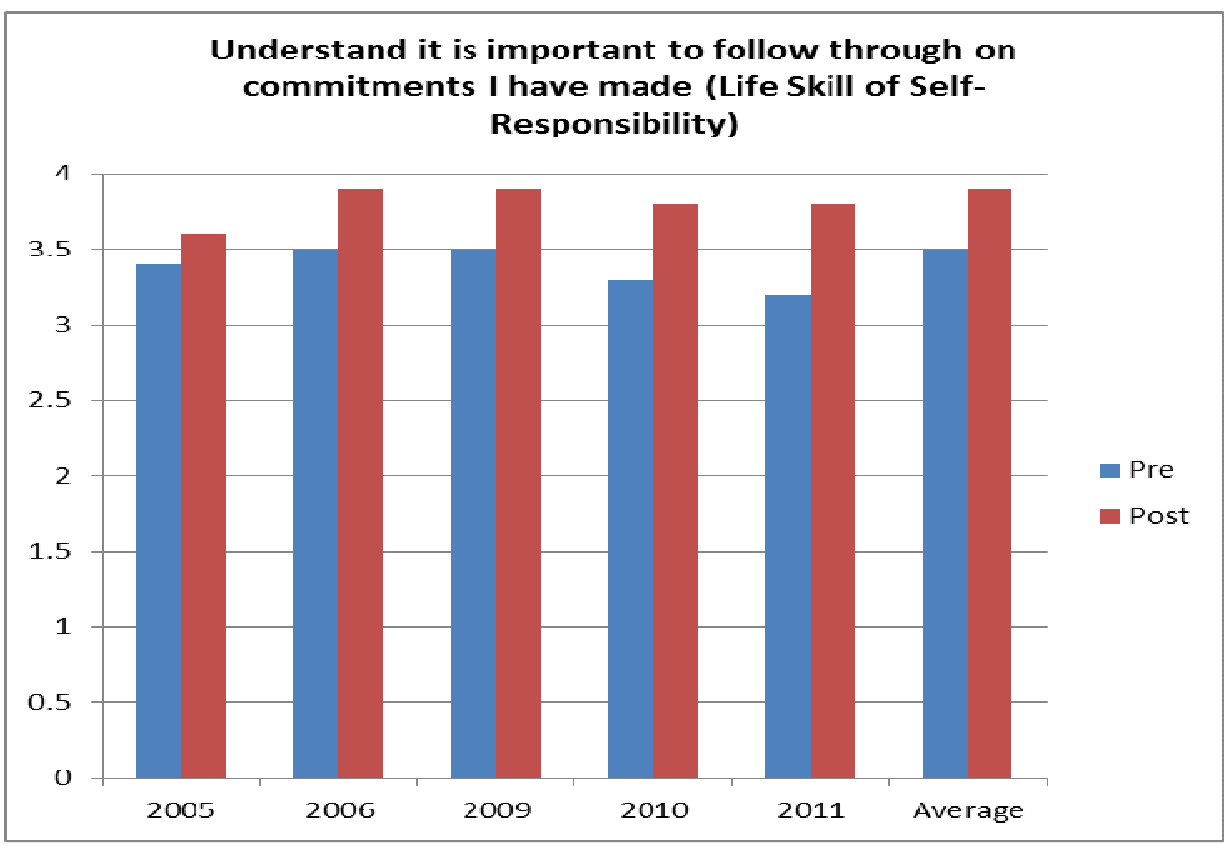

*It can be noted that in several cases the pre scores for 2005-2009 showed a steady increase and then fell in 2010 and 2011. These scores may not be as much representative of the training program, but of a core of experienced counselors who graduated from high school in 2009. Therefore, in 2010 and 2011, the camp counselor team was comprised of $50 \%$ new youth.

\section{Conclusions}

Both the literature and this multi-year study show that young people gain life skills and leadership from the camp counselor experience. The multi-day overnight camping opportunity 
allows for concentrated leadership and life skills experiences not always available in other 4-H venues. In this study, gains were made in life skills areas of accepting differences, leadership, useful/marketable skills, communication, and self-responsibility.

Camp counselors return as volunteers, usually in the position of chaperones in training, at counselor trainings and/or camp itself. Six former counselors have returned as CITs, and in addition, two have already become certified volunteers in the county. Of those who return as $\mathrm{CITs}$, several have been collegiate $4-\mathrm{H}$ members and have recruited additional collegiate 4- $\mathrm{H}$ members to volunteer.

The camp counselor experience needs to be continued as it provides a rich environment for youth development opportunities. However, more study needs to be done. This study indicates that repeated involvement in residential camping positively affects accepting differences, leadership, useful/marketable skills, communication, and self-responsibility. It is likely that the benefits demonstrated by this system would be widely applicable to other youth development organizations, though it would be necessary to conduct further studies to determine this. Another further assessment would be to determine if the duration of the camp has an effect on camp counselor assessments as it would be logical to believe that longer camps result in greater gains. More research needs to be conducted in the area of youth volunteerism as it relates to the residential camp counselor experience.

\section{References}

Arnold, M. (2003). Using multi-site methodology to evaluate 4-H youth leadership retreats. Journal of Extnesion [On-line]. 41(6). Available at:

http://www.joe.org/joe/2003december/rb1.php

Arnold, M., Bourdeau, V.D., \& Nagele, J. (2005). Fun and friendship in the natural world: The impact of Oregon 4-H residential camping programs on girl and boy campers. Journal of Extension [On-line], 46(6), Article No. 6RIB1. Available at:

http://www.joe.org/joe/2005december/rb1.shtml

Brandt, J., \& Arnold, M.E. (2006). Looking back, the impact of the 4-H camp counselor experience on youth development: A survey of counselor alumni. Journal of Extension [On-line], 44(6). Available at: http://www.joe.org/joe/2006december/rb1.shtml

Cemalcilar, Z., (2009). Understanding individual characteristics of adolescents who volunteer. Personality and Individual Differences, 46, 432-436.

Corporation for National and Community Service. (2005). Issue Brief: Youth helping America:

The role of social institutions in teen volunteering. Retrieved August 16, 2010, from http://www.nationalservice.gov/pdf/05 1130 LSA YHA SI factsheet.pdf

Duda, S.L. (2009). Leadership and group facilitation skills in Florida 4-H camp counselors. Unpublished master's thesis, University of Florida, Gainesville. Available at: http://etd.fcla.edu/UF/UFE0024476/duda s.pdf 
Duncan, R.D. (2000). Youth leadership life skills development of participants in the West Virginia 4-H camping program. Unpublished master's thesis, West Virginia University, Morgantown. Available at:

http://wvuscholar.wvu.edu:8881//exlibris/dtl/d3 1/apache media/L2V4bGlicmlzL2R0bC9kM18xL 2FwYWNoZV9tZWRpYS80ODE3.PDF

Forsythe, K., Matysik, R., \& Nelson, K. (2004). Impact of the 4-H camp counseling experience. Department of Youth Development, University of Wisconsin-Extension, Madison, WI.

Retreived from:

http://www.uwex.edu/ces/4h/department/viewdocument.crm?item=Impact\%20of\%20th\%204 \%2DH\%20Camp\%Counseling\%20Experience\%2Epdf

Garst, B.A., \& Bruce, F.A. (2003). Identifying 4-H camping outcomes using a standardized evaluation process across multiple 4-H education centers. Journal of Education [On-line], 41(3). Available at: http://www.joe.org/joe/2003june/rb2.shtml

Garst, B.A., \& Johnson, J. (2005). Adolescent leadership skill development through residential 4-H camp counseling. Journal of Extension [On-line], 43(5). Available at:

http://www.joe.org/joe/2005october/rb5.shtml

Garton, M.S., Miltenberger, M., \& Pruett, B. (2007). Does 4-H camp influence life skill and leadership development? Journal of Extension [On-line], 45(4) article 4FEA4. Available at: http://www.joe.org/joe/2007august/a4.shtml

Hart, D., Donnelly, T.M., Youniss, J., \& Atkins, R. (2007), High school community service as a predictor of adult voting and volunteering. American Educational Research Journal, 44, 197219.

Hines, S., \& Riley, L. (2005). Documenting impact is possible when working with camp program youth leaders. Journal of Extension [On-Line]. 43(3). Available at:

http://www.joe.org/joe/2005june/tt1.php

Logan, R.D. (1985). Youth Volunteerism and instrumentality: A commentary, rationale, and proposal. Journal of Voluntary Action Research, 4, 45-48.

McNeely, N.N. (2004). The Ohio 4-H camp counseling experience: Relationship of participation to personal, interpersonal, and negative experiences. Unpublished doctoral dissertation, The Ohio State University, Columbus. Available at:

http://etd.ohiolink.edu/send-pdf.cgi/McNeely\%20Nicolette\%20Nestor.pdf?osu1095800892

Marta, E., \& Pozzi, M. (2008). Young people and volunteerism: A model of sustained volunteerism during the transition to adulthood. Journal of Adult Development, 15, 35-46.

Morell, V.W., Sharp, P., \& Crandall, S. (2002). Creating student awareness to improve cultural competence: creating the critical incident. Medical Teacher. 24(5). 532-534.

Purcell, L.E. (1996). Does participation in the Georgia 4-H counselor program increase leadership life skills development? Unpublished master's thesis, The University of Georgia, Athens. 
Schaeffer, R. (2006). Key concepts in developmental psychology. Thousand Oaks, California: Sage Publications Inc.

Sundeen, R., \& Raskoff, S. (1994). Volunteering among teenagers in the United States. Nonprofit and Voluntary Sector Quarterly, 23, 383-403.

Thomas, H. (1996). Youth leadership: Teaching essential proficiencies at camp. Camping Magazine, March/April.

Thurber, C.A., et al. (2007). Youth development outcomes of the camp experience: Evidence for multidimensional growth. Journal of Youth Adolescence, 36:241-254.

Toppe, C., Golombek, S., Kirsch, A., Michel, J., \& Weber, M. (2002). Engaging youth in lifelong service- findings and recommendations for encouraging a tradition of voluntary action among America's youth. Washington, DC: Independent Sector.

Underhill, A. (1992). The role of groups in developing teacher self-awareness. ELT Journal. 46(1). 71-80.

Van Linden, J.A., \& Fertman, C.I. (1998). Youth leadership: a guide to understanding leadership development in adolescents. San Fransisco, CA: Jossey-Bass Inc. Publishers.

Yates, M., \& Youniss, J. (1999). Roots of civic identity. Cambridge: Cambridge University Press.

(C) Copyright of Journal of Youth Development Bridging Research and Practice. Content may not be copied or emailed to multiple sites or posted to a listserv without copyright holder's express written permission. However, users may print, download or email articles for individual use. 